\title{
AN ANALYSIS ON THE POLICY IMPLEMENTATION OF ANTIBACTERIAL RESISTANCE CONTROL AT THE HOSPITAL
}

\author{
* Nani Indriana, ** Wiku Bakti B. Adisasmito \\ * Program Studi Ilmu Kesehatan Masyarakat, Fakultas Kesehatan Masyarakat Universitas Indonesia, Kampus Baru UI \\ Depok 16424, Indonesia \\ ** Departemen Administrasi Kebijakan Kesehatan. Fakultas Kesehatan Masyarakat Universitas Indonesia, Kampus Baru \\ UI Depok 16424, Indonesia
}

Email : nani.indriana@gmail.com

\begin{abstract}
In order to control Antibacterial Resistance at the hospital in Indonesia, the Government of Indonesia established an Antibiotics Resistance Control Committee and issued a Regulation from the Ministry of Health, regulation no $8 / 2015$ on an antibiotics resistance control program at the hospital. This is an investigation on the Antibacterial Resistance Control Program (ARCP) at the Hospital, which compares its implementation at a government hospital and a private hospital, Persahabatan Central General Hospital (CGH) and Bogor Indonesian Red Cross Hospital (BIRCH). This was a descriptive study with a qualitative analysis obtained through indepth interviews and documentary research. We discovered that the ARCP was implemented better at Persahabatan CGH compared to BIRCH. Problems include ineffective communication, limited resources, lack of an antibiotic guideline (at BIRCH), lack of coordination between organizations, lack of supervision from the government, and the lack of motivation to implement the policy. These issues can be solved by intensifying the socialization of the policy, conducting more workshops and trainings for private and government hospitals that has not received any, providing an incentive for them to implement the program, such as including ARC into hospital accreditation indicators, and clarifying the benefits of the program to the stakeholders.
\end{abstract}

Keywords: PPRA; Antibacterial Resistance; Hospital; Policy Implementation.

Abstrak. Salah satu upaya pengendalian resistensi antibiotika di Indonesia adalah pembentukan pembentukan Komite Pengendalian Resisten Antibiotika (KPRA) dan diterbitkannya Permenkes no. 8 Tahun 2015 tentang program pengendalian resistensi antibiotika (PPRA) di rumah sakit (RS). Penelitian ini bertujuan untuk menggali lebih dalam terhadap implementasi kebijakan PPRA di RS dibandingkan antara RS pemerintah dengan RS swasta yaitu RS Persahabatan dan RS PMI. Metode penelitian merupakan studi deskriptif dengan analisis kualitatif melalui wawancara mendalam dan telaah dokumen. Hasil penelitian menyimpulkan bahwa pelaksanaan PPRA di RS Pemerintah lebih baik dari RS Swasta. Saran yang diajukan adalah mempercepat peningkatan kesadaran akan pentingnya PPRA, terutama bagi $R S$.

Kata kunci: PPRA; Resistensi Antibiotika; RS; Implementasi Kebijakan

\section{INTRODUCTION}

Health facilities play a large trole in the spread of antibiotic resistance. The inability to identify the microorganisms effectively and efficienly is one of the causes. Another large issue is the misuse of antibiotics, about $50 \%$ of antibiotics prescribed at the hospital were provided incorrectly or unindicated. Other factors include patient requests, financial gain (from drug suppliers), insufficient sanitation, insufficien infection prevention and control at hospitals, and lack of access to appropriate antibiotics (Holmes, 2016; Huttner, 2013; and WHO, 2015). In a previous research, the AMRIN (Antibiotics Resistance in Indonesia-
Prevalence and Prevention) study in two cities in Indonesia, it was found that $43 \%$ of the invididuals that participated in the stud had contracted Multiple Drug Resistant Escherichia coli, which was resistant to: Ampicilln (34\%), Cotrimxazole (29\%) dan Chloramphenicol (25\%). $81 \%$ of patients at the hospital was resistant to Ampicillin (73\%), Cotrimoxazole (56\%), Chloramphenicol (43\%), Ciprofloxacin (22\%), and Gentamycin (18\%) (Kemenkes RI, 2015).

In a 2013 survey at 6 hospitals, it was discovered that 40-60\% of Escherichia coli and Klebsiela pneumonia has produced extended spectrum beta-lactamase (ESBL), which means that the bacteria has developed antibiotic resistance. Several other studies between 2002-2016 
also indicated the presence of Methicillin-Resistant Staphylococcus aureus (MRSA) at various hospitals in Indonesia. Data also indicated that the prevalence of ESBL has continued to increase, from $9 \%$ in 2002 to $45-89 \%$ in 2016 (Chudlori, 2012; Hayati, 2016; KPRA, n.d; Refdanita, 2004; and Tjaniadi, 2003).

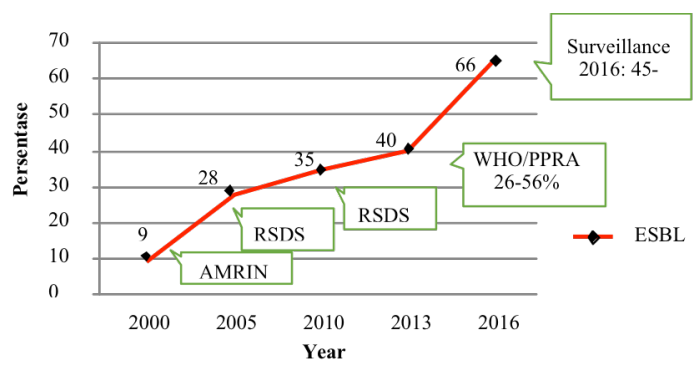

Picture 1. ESBL prevalence in Indonesia between 2002-2016. Source: KPRA 2017

\section{Program for Antibiotic Resistance Control at Hospitals}

To control antibiotic resistance, in 2014 the government established the Antibiotic Resistance Control Committee (ARCC). The Ministry of Health also issues a regulation of the progam in Minister of Health Regulation no. 8/2015 on antibiotic resistance control program (ARCP) at hospitals (ARCP) (Kemenkes RI, 2016 dan Kemenkes RI, 2015). According to theose regulations, hospitals are required to establish an ARCP team. ARCP workshops has been performed since 2010 even before the Minister's regulation was issued. Based on the 2016 ARCP workshop data, we discovered that in 2010, as a pilot project, 20 General Hospitals has performed ARCP workshops (Simões, 2016). However, until 2016 only 112 hospitals has participated in the workshop. The goals of ARCP is to support the four pillars of Antibiotic Resistance Control (ARC), which are clinical microbiology, infection control, clinical pharmacy, and the farmacy committee. Also to improve awareness on antibiotic resistance, to use antibiotics wisely, and to survey the antibiotic resistance and the use of antibiotics.

The ARCP team is responsible for the implementation of the program at the hospital, this includes the planning, organizing, operation, monitoring, and evaluation of the program. Evaluation is done by evaluating the use of antibiotics and monitor the emergence and spread of multiresistant microbes through auditing and surveillance. The program quality indicators include improvement of the quantity and quality of antibiotic use, improving the antibiotic sensitivity pattern, a decreasing pattern in antibiotic resstance, a decrease in multiresistant microbe infection rate at the hospital, and quality improvement in case management of infections through a multidisciplinary integrated infectious cases evaluation forum (Kemenkes RI, 2015). George C Edwards III (1980) in Nawawi (2009) stated that implementation is influenced by four interrelated variables, which are:

1. Effective communication between the policy implementor and the target group. The three indicators to measure it is transmission, clarity, and consistency.

2. Resources. This includes human resources (HR), budget, facility, and authority.

3. Disposition. Which is the characteristics and attitude of policy implementers, such as commitment, honesty, and democratic.

4. Bureaucratic structure. This includes two important things, the mechanism and the organizational structure.

\section{METHODS}

This was qualitative analytic descriptive study. In-depth intervews and documentary research was used to obtain a description and to discover how the ARCP was implemented at the hospital. The research was performed between May-July 2017 at the Ministry of Health, ARCC, Persahabatan Central General Hospital (Persahabatan $\mathrm{CGH}$ ), and the Bogor Indonesian Red Cross Hospital (BIRCH). Informants was chosen usingpurposive sampling.

\section{RESEARCH RESULTS AND DISSCUSION}

Based on the in-depth interviews and documents, we discovered that the problems in the implementation of the policy is divided into 4 aspects, they are:

\section{Communication}

We discovered that the the information distribution between government-owned hospitals and private hospitals was inequal (see table 1). Although both hospitals are the targets of the pocily, however the socialization is still limited to government-owned hospitals and has not reached the private hospitals.

According to Nawawi (2009), there are man ways to socialize a policy, from publicizing the public policy signing ceremony, mass media, to seminars. At Persahabatan hospital, it was done through a 
traning or trainers (ToT), which was to increase the awareness and the abilities of the policy implementers and provide guidance. Information is distributed through workshops and a pocket book of the Permenkes no. $8 / 2015$. However, even this process was not evenly spread. Based on the 2016 ARCP workshop coverage data, only $60 \%$ or 86 of the 144 referral hospitals has completed it. And there is 2,705 hospitals registered in Indonesia. Socialization should be done continously and consistently, therefore reaching all the targets.

The implementing organization must completely understand the goals and aims of the policy, which is controllingantibiotic resistance. If not, according to Subarsono (2016), the targets would reject it. However, not all informants at the private hospitals understand the technical implementation of the ARCP. This problem occurred at the di BIRCH.

The information distributed must also be consistent (Subarsono, 2016). This wasfound to happen at Persahabatan $\mathrm{CGH}$, where even the Functional Medical Staff has received consistent information. However, at $\mathrm{BIRCH}$, not every implementor has understood the technical issues. We believe that the goals and aims of the Permenkes must be described in a job description for them to comprehend it. Appointment through a Team Assignment Letter indicated that they realize that ARC is necessary. To implement it correctly, consistent information must be distributed to and from all the implementers, which includes all the staff at the hospital. To solve that problem, the more ToT programs are necessary at the national/regional referral hospitals, in particular BIRCH.

Table 1. Research Results

\begin{tabular}{|c|c|c|c|}
\hline No & Components & Persuhnbatan CGI & BIRCH \\
\hline \multicolumn{4}{|c|}{ Communication } \\
\hline & Transmission & $\begin{array}{l}\text { ToT by the } \\
\text { Ministry of Health } \\
\text { and ARCC to the } \\
\text { hoopitals. } \\
\text { - Socializing the } \\
\text { ARCP to the } \\
\text { hospital staff: } \\
\text { Improving } \\
\text { comprehension } \\
\text { and compliance of } \\
\text { the staft in using } \\
\text { antibiotics wisely } \\
\text { by socializing the } \\
\text { ARCP and } \\
\text { microbial patterns } \\
\text { during Tuesday } \\
\text { clinical events and } \\
\text { morning roports. }\end{array}$ & $\begin{array}{l}\text { None, because it } \\
\text { is not a } \\
\text { socialization } \\
\text { target. } \\
\text { - Socialize the } \\
\text { ARCP to the } \\
\text { hospital staff: } \\
\text { lmrpoving } \\
\text { the ARCP } \\
\text { team } \\
\text { comprehensi } \\
\text { co of the } \\
\text { ARCP } \\
\text { through mini } \\
\text { workshops. }\end{array}$ \\
\hline & Clarity & $\begin{array}{l}\text { Understand the goals and } \\
\text { aims of the policy }\end{array}$ & $\begin{array}{l}\text { Understand th goals } \\
\text { and aims }\end{array}$ \\
\hline & Consistency & $\begin{array}{l}\text { Understand the technical } \\
\text { matters }\end{array}$ & $\begin{array}{l}\text { Do not comprehend } \\
\text { the technical matters }\end{array}$ \\
\hline
\end{tabular}

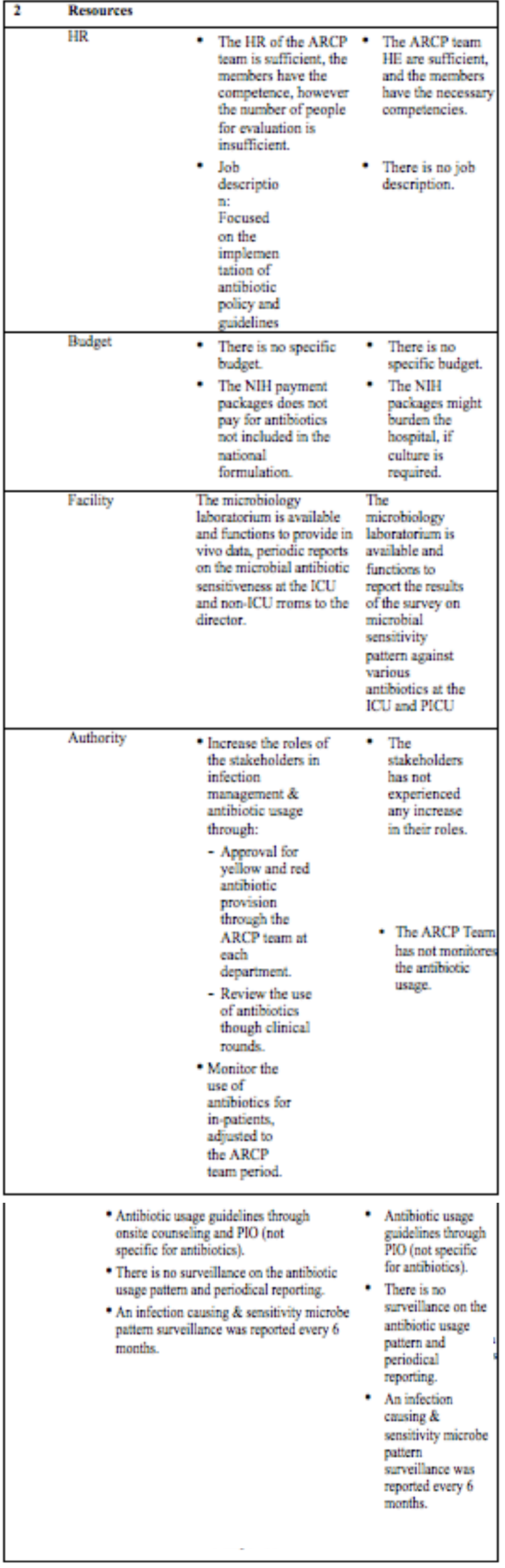




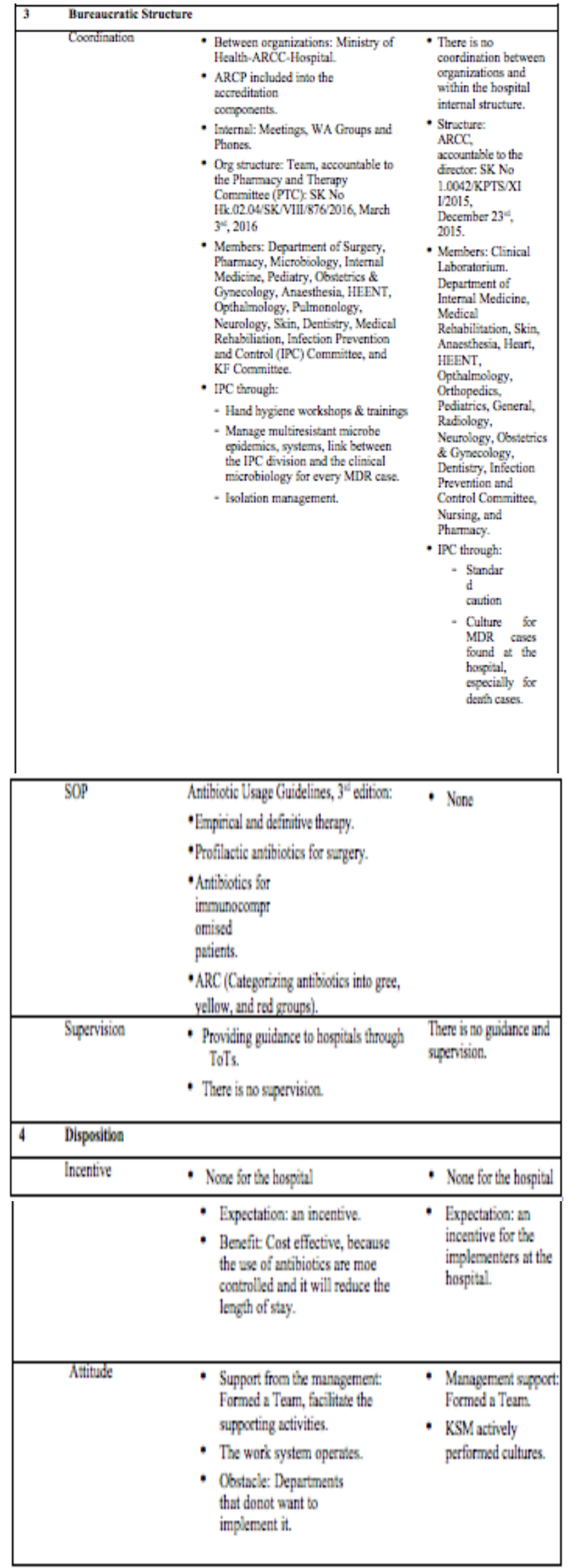

\section{Resources}

Humans are the most important resource in the success of policy implementation (Subarsono, 2016). Certain stages of the implementation process requires compenent HR. As stated in table 1, we discovered that the HR at Persahabatan CGH were competent and appropriate for this policy, each team member has the competencies regulated in the Minister's regulation. Available competent resources should mean that they perform their jobs well, but in reality, there were HR that weren't able to perform the evaluation. We discovered that every individual holds more than one position, sothey have to complete their daily tasks and perform the ARCP team tasks. However, at BIRCH, although there were members that had the competencies, they have not operated, mostly because of the lack of motivation became the obstacle in the implementation.

Facilities that guarantees the implementation of the ARC policy is also an important factor. According to the informants, the main facility that supports this policy was a well-run microbiology laboratorium. Without it, the policy cannot be implemented. The clinical microbiology laboratorium isolates and identifies the microbes, determine the antibiotic sensitivity pattern, performs epidemiology surveillance, and epidemic detection (Simões, 2012). Both hospitals have a microbiology laboratorium, therefore there is no problem in the facilities.

Financial resources is also crucial in the implementation. Each program needs financial support for the staff to perform administrative tasks and in monitoring the program. In the government hospital, the budget comes from the National Budget, and this is used for socialization and guidance. However, because of budget cuts and priority programs, the current budget is insufficient for continuing socialization and guidance. At both hospitals, the financial problem is at the NIH package payments. The Persahabatan CGH stated that the NIH package payments do not finance antibiotics that is not included in the national formularium, and the hospital must pay for it, which is a burden because of the high number of MDR cases. BIRCH stated that the NIH package payments cannot cover the cost for microbial cultures, and therefore would inconcivience the hospital. BIRCH is a pure private hospital, where all of the operating costs are covered by the patient, and $90 \%$ of the patients are NIH patients. Actually, this should have encourage the hospital to implement the ARCP immediately. ARCP will minimalize the morbidity and mortality, length of stay, and increasing treatment costs (Negara, 2014). 
Edward in Winarno (2014) stated that with policy instruments, policy implementors can optimalize the time used and standardize the procedures in a complex and wide organization. According to Permenkes no. 8/2015, the hospital must compile the antibiotic usage guidelines. At Persahabatab $\mathrm{CGH}$, the $3^{\text {rd }}$ Antibiotic Usage Guidelines was created and it acts as a guidelines for the ARCP team in approving antibiotic provision, particularly yellow and red antibiotics. However, $\mathrm{BIRCH}$ does not have one.

Based on the analysis above, all four variables influence the implementation the policy at both hospitals. As a solution ,the hospital must appoint a person that is interested in the field of infection as the head of the ARCP team, therefore providing good leadership, and microbial exainations must be included in the clinical pathway, therefore the hospital is required to perform a bacterial culture. To guarantee the continuance of the program, mini workshops to prepare for the following stages.

\section{Bureaucratic Structure}

The Ministry of Health and the ARCC has coordinated with the government hospitals for this policy, however not the Health Office. Although the health office and the regional leader are the ones that should guide and supervise this program. There is also no coordination with private hospitals. At Persahabatan $\mathrm{CGH}$, the ARCP team has coordinated with the 6 ARC pillars, which are the microbiology laboratorium, pharmacy, PTC, IPC Committee, Doctors/Functional Medical Staff (FMS), and Nurses. Although not all work within the ARC team, ultimately the activities are meant to control antibiotic resistance. However, at BIRCH the activities of the ARCP pillars have not reflected antibiotic resistance control.

Supervision is another problem. According to Permenkes no. $8 / 2015$, the Minister, Governor, and Mayor/Regent with the ARCC, hospital association, and related professional organizations are the ones that should've guided and monitor the ARCP. Supervision and guidance is provided through advocacy, socialization, technical guidance, trainings to improve the capacity of HR, and monitoring and evaluation. Only the government-owned hospitals has been supervised, not the private hospitals. The supervision at Persahabatan CGH was done through a ToT, where the national and regional referral hospitals are expected to become an extension of the ARCC in providing guidance for the hospitals within their area. Guidance and socialization should be done continuously and consistently and not only at government hospitals.

To solve both problems, the ARCP team must perform a meeting that discusses the main tasks and functions of the ARCP Committee, determine the program target, and determine which medical staff group should be the pilot project for the policy. The team should also conduct a meeting with the stakeholders to establish the antibiotic guidelines.

\section{Disposition}

According to Edward (1980) in Supriadi (2012), to implement a policy effectively, the implementors not only must know what they must do and has the capabilities to perform it, they must have the will to do it. At Persahabatan $\mathrm{CGH}$, the management has provided positive support by facilitating the ARCP, forming a team, and issue an antibiotic guideline. The team has also begin to perform monitoring. Although there were some departments that does not agree to implement the antibiotic approval mechanism at the hospital. This is mostly because the team has not approached the department and the departments were not required to follow the policy. Solving this requires consistent and continuing socialization to each personnel.

The management at BIRCH also has supported this program by forming a ARCP team and conducting a mini workshop to provide information on the ARCP. Rejection comes from teams that have not implemented the ARCP. This was because the team does not have a clear job description and uneven information distribution and comprehension on the technical aspects of ARCP.

According to Subarsono (2016), the implementation process incentive and punishments are required to implement a policy successfully. The incentive system is meant to increase motivation to reach the organizational goals. However, this program does not provide an incentive, because the implementation of this program is a part of the task and functions of the hospital.

In article 15 of the Permenkes, hospitals that violate the regulations can be punished with an administrative sanction, which may be oral or written warnings. However, we do not consider it applicable, since there is guidance and supervision from the Minister, Governor, or Mayor/Regent. Including the ARCP as one of the indicators in the hospital accreditation is the most appropriate incentive for hospitals. 


\section{Summary}

The implementation of the ARCP at hospitals has met many problems. Among them were ineffective communication; limited human resources, limited budget, lack of authority; lack of an antibiotic guideline (at BIRCH); lack of coordination between organizations; lack of supervision from the government, ARCC, and the local health office; lack of coordination between the government, the hospitals and the stakeholders; and the lack of motivation for the implementers to implement the policy. These issues can be solved by intensifying the socialization of the policy, conducting more workshops and trainings for private and government hospitals that has not received any, providing an incentive for them to implement the program, such as including ARC into hospital accreditation indicators, and clarifying the benefits of the program to the stakeholders.

\section{REFERENCE}

Chudlori B, Kuswandi M, dan Indrayudha P. (2012). Pola Kuman dan Resistensinya Terhadap Antibiotika dari Spesimen Plus di RSUD Dr. Moewardi Tahun 2012. Jurnal Farmasi

Data Workshop PPRA RS Rujukan. (2016). Jakata: Kemenkes RI.

Hayati, Z., Azwar, A., \& Puspita, I. (2016). Pola dan Sensitivitas Antibiotik Bakteri Yang Berpotensi Sebagai Penyebab Infeksi Nosokomial di Ruang Rawat Bedah RSUDZA Banda Aceh. YARSI Medical Journal vol. 20(3), hal. 158-166. Diunduh dari: http://academicjournal.yarsi.ac.id/index.php/jurna 1-fk-yarsi/article/view/168/104 pada tnaggal 17 Maret 2017.

Holmes AH, Moore LSP, Ord S, et al. (2016). Understanding the mechanisms and drivers of antibiotics resistance. Antibioticss: Access and Sustainable Effectiveness vol. 387(10014): 176187.

Huttner A, Harbarth S, Carlet J, et al. (2013). Antibiotics resistance: a global view from the 2013 World Healthcare- Associated Infections Forum. Antibiotics Resistance and Infection Control, 2(31):13.

Kemenkes RI. (2015). Permenkes RI No. 8 Tahun 2015 tentang PPRA di RS. Hukor Depkes RI. Jakarta. Diunduh dari:
https://doi.org/10.1017/CBO978110741532 4.004 .

KPRA. (n.d.). KPRA. Retrieved March 17, 2017. Diunduh dari: https://kpra.wordpress.com/

Moeloek FN. (2015). Tantangan dan Komitmen dalam Penanganan: Antibiotics Resistance (AMR) di Indonesia - Sehat Negeriku. Diunduh dari http://sehatnegeriku.kemkes.go.id/ baca/blog/20150629/1912686/tantangan-dankomitmen-dalam-penanganan-antibioticsresistance-amr-di-indonesia/ pada tanggal 17 Maret 2017.

Nawawi, I. (2009). Public Policy: analisis, strategi. advokasi dan praktek. Jakarta: Putra Media Nusantara.

Negara, S. K. (2014). Analisis Implementasi Kebijakan Penggunaan AntibiotikaRasional Untuk Mencegah Resistensi Antibiotika di RSUP Sanglah Denpasar: Studi KasisInfeksi Methicillin Resistant Staphylococcus Aureus. ARSI, 1(1), 42-50. Retrieved from http://journal.ui.ac.id/index.php/arsi/article/vie wFile/5211/3496

Refdanita, Maksum R, Nurgani A, dan Endang P. (2004). Pola Kepekaan Kuman Terhadap Antibiotika di Ruang Rawat Intensif RS Fatmawati Jakarta Tahun 2001-2002. Makara Kesehatan vol. 8(2), hal. 41-48. Diunduh dari http://journal.ui.ac.id/index.php/health/article/v iewFile/293/289 pada tanggal 17 Maret 2017.

Simões AS. (2016). Prevention and Control of Antibiotics Resistant HealthcareAssociated Infections: The Microbiology Laboratory Rocks! Front Microbiol vol. 7, hal. 855. Diunduh dari http://www.ncbi.nlm.nih.gov/pmc/articles/P MC4895126/ pada tanggal 17 Maret 2017.

Subarsono, A. (2016). Analisis Kebijakan Publik: Konsep, Teori dan Aplikasi. Yogyakarta: Pustaka Pelajar.

Supriadi A. (2012). Analisis Prakondisi Implementasi Kebijakan Peningkatan Kompetensi Guru. Jurnal Pendidikan Dan Pembelajaran (JPP). 
Tjaniadi P, Lesmana M, Subekti D, et al. (2003). Antibiotics Resistance of Bacterial Pathogens Associated with Diarrheal Patients in Indonesia. The American Journal of Tropical Medicine and Hygiene vol. 68(6), hal. 666-670.

Winarno, B. (2012). Kebijakan Publik: Teori, Proses dan Study Kasus. Yogyakarta: CAPS

World Health Organization. (2015). Global Action Plan on Antibiotics Resistance. Geneva: WHO Document Production Series. 